\title{
Osteogenesis imperfecta and cerebrospinal fluid leak: a unique presentation and treatment challenge
}

\section{Osteogênese imperfeita e fístula rinoliquórica: apresentação única e desafio ao tratamento}

Clara Mota Randal Pompeu1. Anna Caroline Rodrigues de Souza Matos¹. Mirian Mota Randal Pompeu². Luis Fernando Falcão de Castro Meireles ${ }^{2}$. Daniel Aguiar Dias¹. Erika Ferreira Gomes ${ }^{1}$.

1 Hospital Universitário Walter Cantídio (HUWC), Universidade Federal do Ceará (UFC), Fortaleza, Ceará, Brasil. 2 Universidade de Fortaleza (UNIFOR), Fortaleza, Ceará, Brasil.

\begin{abstract}
Introduction: Osteogenesis imperfecta (OI) is a heritable disorder of the connective tissue that mainly manifests as bone fragility. Other signs and symptoms may be present, such as sensorineural hearing loss, cardiac malformations, and teeth alterations. Case description: 72-year-old female patient presented with left abundant spontaneous hyaline rhinorrhea, history of several bone fractures since early childhood, and a blue grayish sclera was noted. Cerebrospinal fluid (CSF) leak was diagnosed. Neuroimaging revealed lowering of the sella turcica floor, platybasia, basilar impression, left middle fossa calcified meningioma, syringobulbia, ventricular dilatation, and left ethmoidal fistula. Due to the patient's age and clinical status, a medical approach was chosen, and treatment with acetazolamide and furosemide in low dosages, which resulted in a decrease of the rhinorrhea. Discussion: Clinical features and imaging study are often sufficient for diagnosis of OI. The neurological and cranial features in OI are varied. CSF leak is not commonly reported and might have been a consequence of bone softening and hydrocephalus. Conclusions: This case represents a treatment challenge, as the surgical results were uncertain, once bone fragility could result in the development of new leaks. Clinical treatment was chosen and resulted in a significant improvement of the symptoms.
\end{abstract}

Keywords: Osteogenesis imperfecta. Cerebrospinal fluid. Hydrocephalus. Bone diseases.

\section{RESUMO}

Introdução: Osteogênese imperfeita (OI) é um distúrbio hereditário do tecido conectivo, que se manifesta principalmente com fragilidade óssea. Outros sinais e sintomas podem estar presentes, tais como perda auditiva neurossensorial, malformações cardíacas e alterações dentárias. Descrição do caso: Paciente sexo feminino, 72 anos, com rinorreia hialina espontânea abundante, história de fraturas ósseas múltiplas, desde a infância e esclera azul acinzentada. Foi realizado o diagnóstico de fístula rinoliquórica. Imagens de sistema nervoso central mostraram rebaixamento do assoalho da sela túrcica, platibasia, impressão basilar, meningioma de fossa média calcificado, siringobulbia, dilatação ventricular e fístula etmoidal à esquerda. Devido idade e estado clinico da paciente, foi optado por uma abordagem medicamentosa, sendo iniciado tratamento com acetazolamida e furosemida, em doses baixas, resultando em diminuição da rinoliquorreia. Discussão: Achados clínicos e exames de imagem são, em geral, suficientes para o diagnóstico de OI. As características neurológicas e cranianas da OI são variadas. Fístula rinoliquórica não é um achado comum e pode ter sido consequência da fragilidade óssea e da hidrocefalia. Conclusão: Esse caso representa um desafio ao tratamento. Os resultados cirúrgicos são incertos, pois a fragilidade óssea pode resultar no surgimento de novas fístulas. Tratamento clínico resultou em redução significante da rinoliquorreia.

Palavras-chave: Osteogênese imperfeita. Líquido cefalorraquidiano. Hidrocefalia. Doenças ósseas.

Corresponding author: Clara Mota Randal Pompeu, Capitão Francisco Pedro Street, 1290, Rodolfo Teófilo, Fortaleza, Ceará, Brasil. Zip Code 60430-372. Phone: +55 85 3366-8616. E-mail: claramrp@gmail.com

Conflict of interests: The authors have no conflicts of interest to declare.

Received: 15 Aug 2018; Revised: 20 Mar 2019; Accepted: 03 Apr 2019. 


\section{INTRODUCTION}

Osteogenesis imperfecta (OI) is a heritable disorder of the connective tissue involving the extracellular matrix and manifesting with bone fragility. The disease has phenotypic and genotypic heterogeneity, and can affect the musculoskeletal system, skin, sclera, teeth, ear, and cardiovascular system. ${ }^{1,2}$

The prevalence of OI is 1 in 10,000-20,000 births, $80 \%$ of cases are due to mutations in two genes that encode type I collagen, COL1A1 or COL1A2, located on chromosomes $17 q 21.33$ and $7 q 22.1$. Such mutations result in quantitative or structural defects in collagen and increased bone turnover, and $90 \%$ of cases are autosomal dominant. ${ }^{1-4}$

\section{CASE REPORT}

A 72-year-old female patient presented with left abundant spontaneous hyaline rhinorrhea, for seven months.

Patient had a history of several fractures and repeated falling and was undergoing clinical assessment for pathological bone fractures. The patient's sclera had a blue grayish color (Figure 1). Patient's daughter presented with blue sclera, hearing loss that was diagnosed as otosclerosis, and had a history of multiple bone fractures. There were two similar cases in the family.

Figure 1. Detail of patient's eyes showing blue grayish sclera.

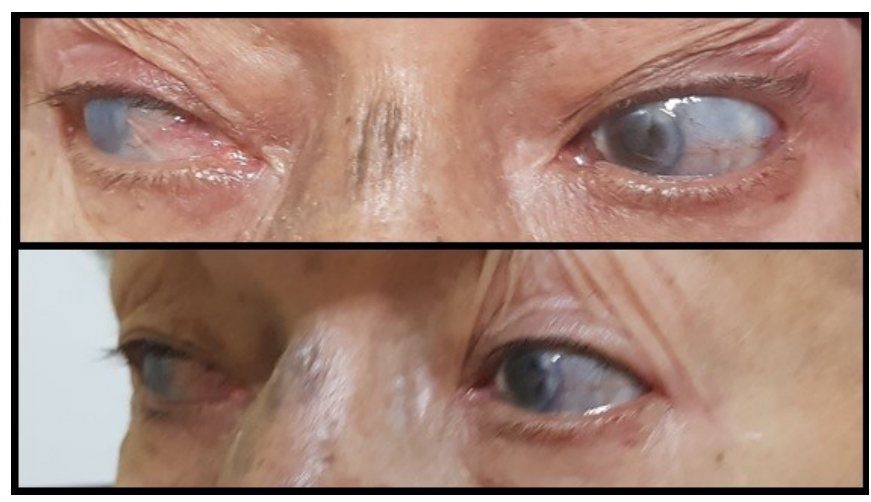

Glucose levels in the nose fluid and serum were measured simultaneously, 77 and $117 \mathrm{mg} / \mathrm{dL}$, respectively, thereby supporting the diagnosis of cerebrospinal fluid (CSF) leak.

Bone scintigraphy showed areas suggestive of an increase in osteoblastic activity. Lumbar and thoracic magnetic resonance imaging (MRI) revealed multiple vertebral bodies deformities, pathological compressive fractures, and kyphoscoliosis. A full hematological and endocrinological investigation revealed no remarkable findings.

Computed tomography (CT) of the sinuses showed a possible bone discontinuity in the left cribriform plate, a left ethmoidal osteoma, diffuse reduction of bone density, lowering of the sella turcica's floor, platybasia, basilar impression, and a left middle fossa calcified meningioma (Figure 2). Brain MRI revealed a significant basilar impression, syringobulbia, important ventricular dilatation (hydrocephalus), and a left ethmoidal fistula (Figure 3).

Bone densitometry revealed a low bone mineral density (BMD), compatible with osteoporosis. Audiogram showed a mixed bilateral hearing loss.

The diagnosis of Osteogenesis Imperfecta was established. The patient had already begun treatment with bisphosphonates, and acetazolamide was initiated for the hydrocephalus. Furosemide was added afterwards. Due to the patient's age and clinical status, medical management and close ambulatory follow-up was chosen. After a one-month course of medication, patient presented with significant improvements in the rhinorrhea.

Figure 2. Coronal plane - patient's sinuses CT presenting bone discontinuity in the left cribriform plate.

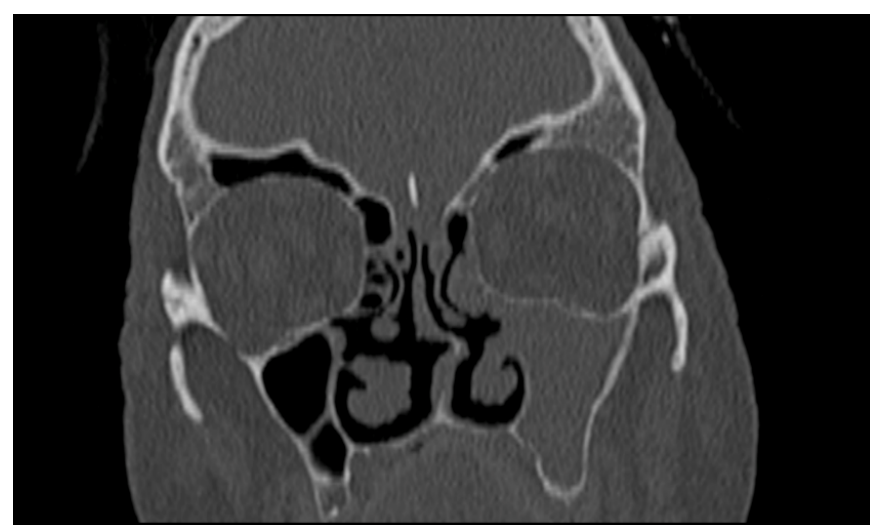

Figure 3. Sagittal plane - patient's T2 brain MRI showing basilar impression, syringobulbia and hydrocephalus.

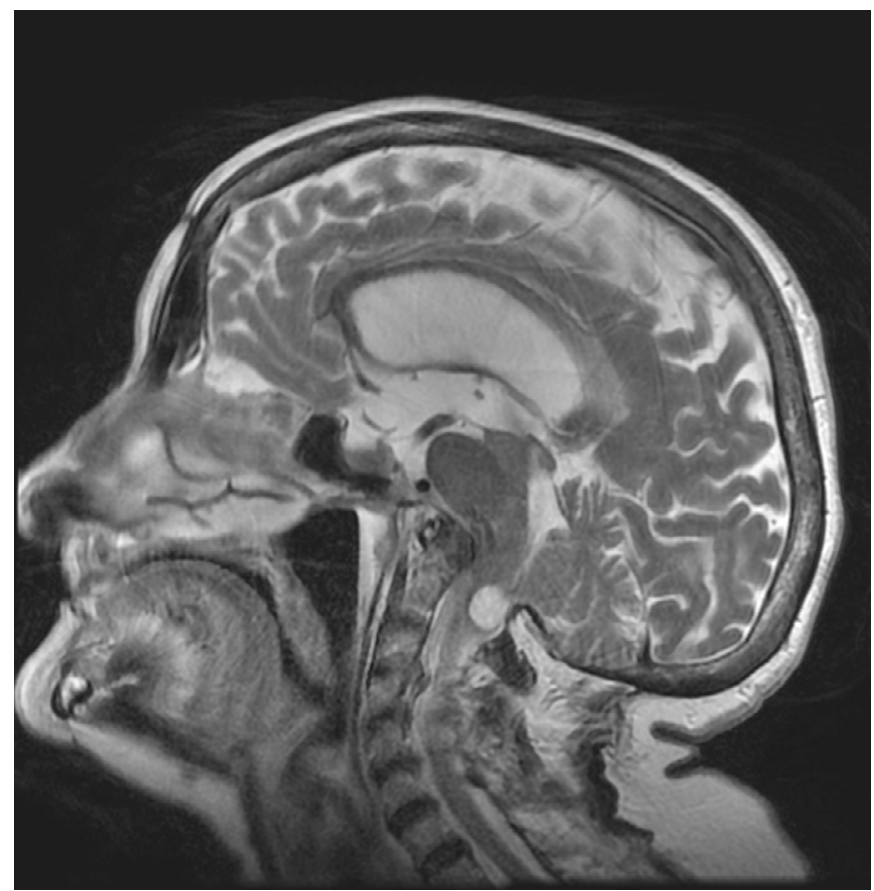




\section{DISCUSSION}

$\mathrm{OI}$ is a heterogeneous disease, with presentations ranging from a subtle increase in the incidence of fractures to life threatening forms. ${ }^{1,4}$ Bone fragility is a feature common to all types of OI. ${ }^{5}$ In 1979, Sillence et al. developed a classification system for OI, consisting of four types (I to IV), that involve autosomal dominant disorders, whereas types V to XI, which have only recently been described, involve a variety of dominant and recessive genotypes. ${ }^{1,6,7}$

Type I is the most common. It is a non-deforming subtype, associated with low bone mass and elevated incidence of long-bone fractures. Patients usually present with blue or gray sclera, and precocious hearing loss. A slight reduction in life expectancy is expected. ${ }^{1,4}$

Type II is a lethal perinatal form. Being the least common, its effects are most pronounced in the bones, and in utero fractures are a hallmark. It is possible to diagnose type II before birth. Affected babies usually die within the first year of life because of respiratory failure or cerebral hemorrhage. ${ }^{1,4}$ Type III is characterized by severe bone fragility, short stature, and kyphoscoliosis. ${ }^{1,4}$ Type IV ranges from moderate to severe and is marked by recurrent fractures. A variable severity and a small reduction in life expectancy is expected. ${ }^{1,4}$

Clinical features and imaging study results are often sufficient for diagnosis. Nevertheless, lumbar spine bone mineral density, bone biochemistry, and the exclusion of possible metabolic causes of osteoporosis are helpful. Genetic testing is also important, but not necessary, given its high cost and limited availability. ${ }^{1,5}$

As for other OI manifestations, there is a vast number of signs and symptoms.

Bone fragility, muscle wasting, and immobilization render fractures an important aspect of OI, affecting axial and appendicular skeletons. Bone deformities result from excessive malleability and plasticity in addition to ligament laxity and joint hyperflexibility.

Half of patients, by the age of 50, have developed mild to profoundly severe bilateral hearing loss. It usually appears in the second to fourth decade of life as a form of conductive impairment and evolves to a mixed hearing loss thereafter. ${ }^{2,6}$ The Van der Hoeve-de Kleyn syndrome is the triad of fragile bone, blue sclerae, and progressive hearing impairment that was first described in $1917 .{ }^{8}$

The hearing loss in OI is related to otosclerosis-like focus seen near the oval window, abnormal bone remodeling, fixed and thickened staples footplate, and ossicular discontinuity can also be present. ${ }^{2,7}$ Meanwhile, bone abnormalities, atrophy of the stria vascularis and labyrinthine hemorrhage are suspected of contributing to sensorineural hearing involvement. ${ }^{2}$

Teeth involvement is present in $28 \%$ of cases, being weak, translucent, and discolored. It particularly affects the first dentition, a feature known as detinogenesis imperfecta. ${ }^{1,6}$
The neurological and cranial features in OI are diverse. In total, $60 \%$ of OI patients present with Wormian, or intra sutural bones. ${ }^{6}$ Macrocephaly and hydrocephalus represent the most common cranial abnormalities (Figure 4). Triangular-shaped face, prominent forehead, mandibular malformation, and brachycephaly due to premature fusion of the coronal sutures are other possible manifestations. ${ }^{4,6}$

Bone softening may lead to craniocervical junction abnormalities, such as platybasia, basilar impression, and basilar invagination. ${ }^{4} \mathrm{~A}$ protrusion of the odontoid process into the intracranial space marks the basilar invagination, while an upward infolding of the foramen magnum causes basilar impression. ${ }^{4}$

There are some parameters to evaluate these alterations, such as the McRae line, drawn anteroposteriorly in the foramen magnum to measure basilar invagination. For basilar impressions, the Chamberlain line is drawn from the posterior edge of the hard palate to the posterior margin of the foramen magnum, while the McGregor line extends from the posterior edge of the hard palate to the most caudal aspect of the occiput. Platybasia is defined as a flattening of the skull base, when the basal angle is greater than $145^{\circ}$ (Figure 5).,

These abnormalities can compress the brainstem, cerebellum, and cranial nerves, thereby resulting in hydrocephalus, aqueduct stenosis, cord edema, and syrinx. MRI is the best imaging available for assessing these cases. ${ }^{3,4,6} \mathrm{~A}$ wide range of symptoms may result from basilar invagination, which is the most common neurologic complication, such as headache, nystagmus, ataxia, and cranial nerves impingement. ${ }^{3,6}$

Figure 4. Axial plane - patient's T2 Brain MRI revealing severe hydrocephalus.

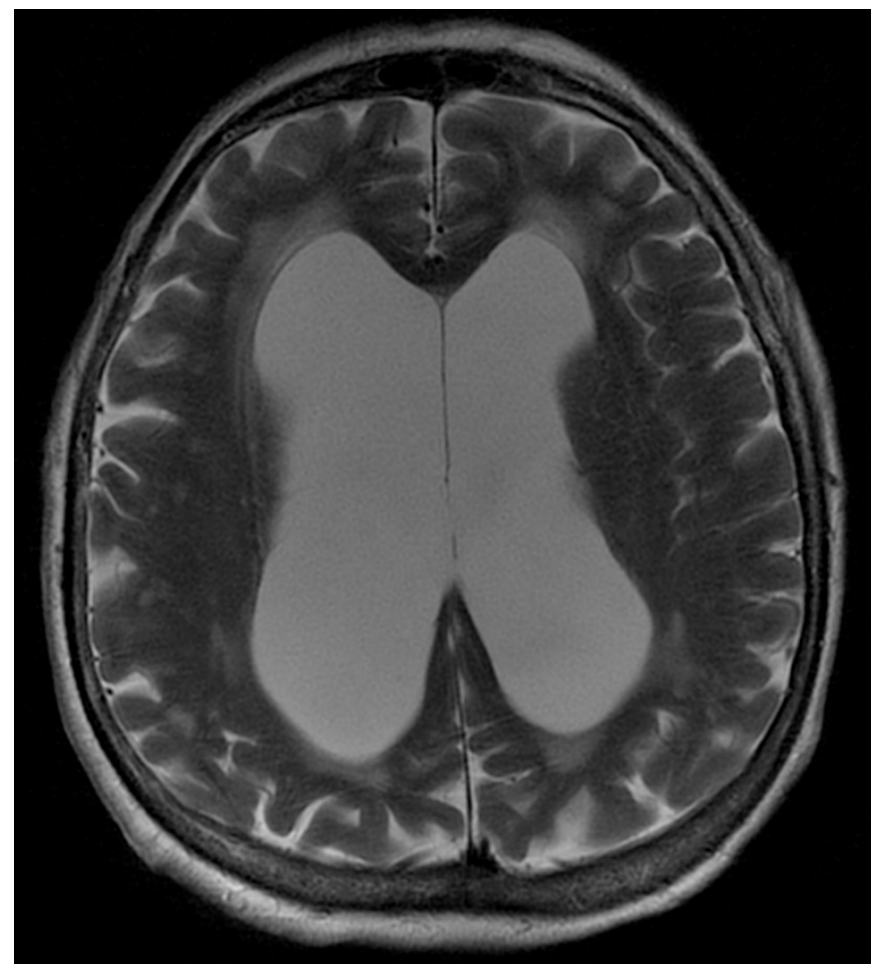


Figure 5. Sagittal plane - patient's brain CT with a marked basal angle of $151^{\circ}$.

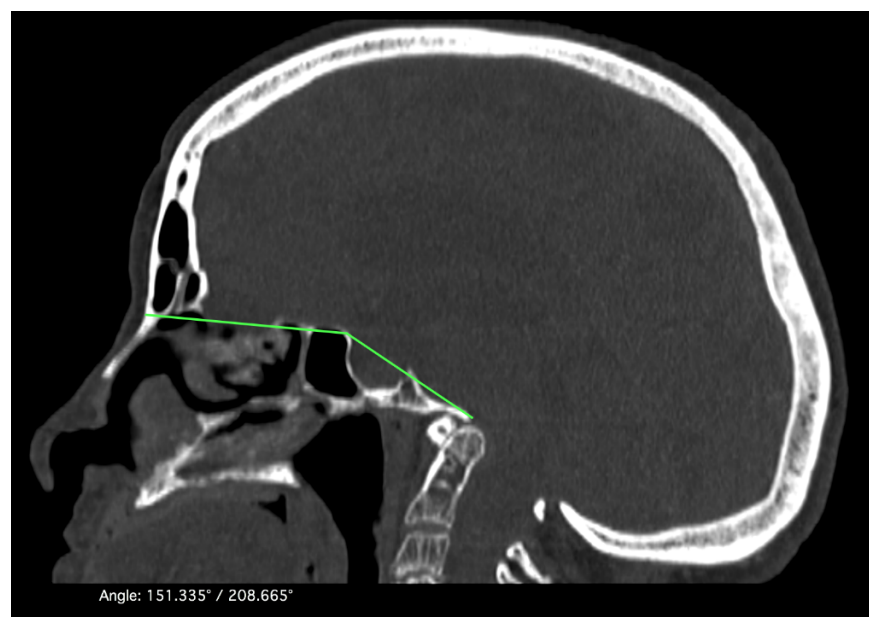

Studies have shown that $25 \%$ of OI patients present with basilar impression, and $50 \%$ of these patients present with neurologic signs of posterior fossa compression. Although basilar impression may be present before puberty, a slow progression is observed and patients remain asymptomatic for prolonged periods of time. Pyramidal tract signs, imbalance, and limb weakness are potentially serious complications. ${ }^{9}$

Hydrocephalus is associated, and impaired outflow of cerebrospinal fluid, venous outflow obstruction, and skull base deformities, such as widening of the basal cistern and ventral sella, can cause generalized cerebral atrophy. ${ }^{4}$

Diffuse osteopenia and defective cortical bone formation, associated with hydrocephalus, result in increased intracranial pressure. This could lead to damage of the skull base, with subsequent CSF leak.

OI can affect the spine, causing sclerosis of vertebral endplates, biconcave vertebral bodies, flattening of the thoracic vertebrae, and elliptic intervertebral disks spaces. When there are fractures, spinal cord compression is often observed. ${ }^{3,4}$

\section{REFERENCES}

1. Palomo T, Vilaça T, Lazaretti-Castro M. Osteogenesis imperfecta: diagnosis and treatment. Curr Opin Endocrinol Diabetes Obes. 2017;24:381-8.

2. Swinnen FK, De Leenheer EM, Goemaere S, Cremers CW, Coucke PJ, Dhooge IJ. Association between bone mineral density and hearing loss in osteogenesis imperfecta. Laryngoscope. 2012;122(2):401-8.

3. Debette S, Germain DP. Neurologic manifestations of inherited disorders of connective tissue. In: Biller J, Ferro JM, eds. Handbook of neurology. Paris: Elsevier; 2014. p. 565-76.

4. Khandanpour N, Connolly DJ, Raghavan A, Griffiths PD, Hoggard N. Craniospinal abnormalities and neurologic complications
Treatment strategies vary according to the severity of the disease, age, and functional status of patients. The impact of the disease ranges from subtle restrictions, such as avoiding contact sports, to orthopedic interventions and rehabilitation. ${ }^{1}$ The goals of treatment are to maximize mobility and competencies, as well as to decrease bone pain and fragility. ${ }^{6}$ Bisphosphonates represent an important advancement in treatment as it increases BMD and reduces the risk of vertebral fractures..$^{1,3,4}$ Vitamin D also has an important role in reducing the risk of fractures. ${ }^{3}$

\section{CONCLUSIONS}

The patient initially complained of symptoms related to CSF leak. This is unique presentation, along with the medical history and complementary exams, led to the diagnosis of OI. Although hydrocephalus and craniocervical abnormalities were verified by imagining, the patient did not exhibit neurological symptoms. This may have been due to the CSF leak, which may have reduced the intracranial pressure to normal levels. Thus, this case demonstrates that identifying the underlying causes of presumed idiopathic CSF leaks is critical to patient treatment.

Furthermore, treating the patient in this case is challenging itself. In particular, determine whether the hydrocephalus or the CSF leak should be corrected first is critical to ensuring good patient outcomes. Considering that the CSF leak is a consequence of hydrocephalus, it must be treated first to prevent the progression of the leakage. Repairing the CSF leak is necessary, to reduce the risk of complications, such as meningitis. In OI, however, bone fragility may reduce the efficacy of surgery, since, even if the fistula repair is successful, new CSF leaks may develop subsequently at other sites. In the present case, medical therapy was performed and the patient is currently responding well to acetazolamide, associated with furosemide, with a considerable reduction in the severity of her rhinorrhea.

Therefore, more studies are needed to establish a clinical treatment for OI that could improve bone mineral density, prevent complications, and enhance surgical outcomes.

of osteogenesis imperfecta: imaging overview. Radiographics. 2012;32(7):2101-12.

5. Fotiadou AN, Calleja M, Hargunani R, Keen R. Skeletal manifestations of osteogenesis imperfecta. Semin Musculoskelet Radiol. 2016;20(3):279-86.

6. Harrington J, Sochett E, Howard A. Update on the evaluation and treatment of osteogenesis imperfecta. Pediatr Clin North Am.2014;61(6):1243-57.

7. Swinnen FK, Dhooge IJ, Coucke PJ, D'Eufemia P, Zardo P, Garretsen TJ, et al. Audiologic phenotype of osteogenesis imperfecta: use in clinical differentiation. Otol Neurotol. 2012;33(2):115-22 
8. Reinstein E, Pariani M, Bannykh S, Rimoin DL, Schievink WI. Connective tissue spectrum abnormalities associated with spontaneous cerebrospinal fluid leaks: a prospective study. Eur J Hum Genet. 2013;21(4):386-90.
9. Pinter NK, McVige J, Mechtler L. Basilar invagination, basilar impression, and platybasia: clinical and imaging aspects. Curr Pain Headache Rep. 2016;20(8):49.

\section{How to cite:}

Pompeu CM, Matos AC, Pompeu MM, Meireles LF, Dias DA, Gomes EF. Osteogenesis imperfecta and cerebrospinal fluid leak: a unique presentation and treatment challenge. Rev Med UFC. 2019 out-dez;59(4):74-78. 